\title{
Birds of Prey - Feeding Habits
}

\author{
RONALD HOOPER, Somme, Sask.
}

GOSHAWK - feeds on poultry and young birds. One January day several years ago I was on the way for a load of straw, when suddenly a Goshawk came near, flying laboriously with a Sharp-tailed Grouse in its talons. I yelled at him and he dropped the grouse which I quickly retreaved. Being robbed of his delicious meal, the angry hawk picked a fight with a Snowy Owl. The two birds sat in the snow about ten feet apart, glaring at each other like a pair of fighting roosters. Suddenly they leaped forward and met in mid-air, talons foremost. They then sank back to the ground to repeat the performance. They kept it up for about fifteen or twenty minutes, then they gave up and separated.

THE SHARP SHINNED HAWK -feeds on small birds, largely spar rows. One day last spring I wanted a Crested Flycatcher for our collection of mounted birds. I shot at one and wounded it. The poor wounded bird hovered in mid-air, when suddenly a Sharp-shinned Hawk whipped out of a grove of spruce, seized the Flycatcher and made a hasty retreat with it.

THE RED - TAILED HAWK feeds on squirrels, mice and other small mammals. One day, last summer, a Red-tailed Hawk decided to tackle a mother hen and her chicks in our yard. Being inexperienced at catching birds he did not swoop on them like an accipter. Instead, he landed on the ground beside them. The mother hen put her chickens behind her and jumped up at the hawk. The bewildered hawk just sat there while the hen grew more excited by the moment. My mother rushed from the house and screamed at the hawk. This forced him to act fast, so he rushed forward, siezed a little chicken and flew away with it. The hawk cannot be blamed for this rare incident, as mammals were very scarce in our district last summer.

THE BROAD-WINGED HAWK -feeds on small mammals. Since they

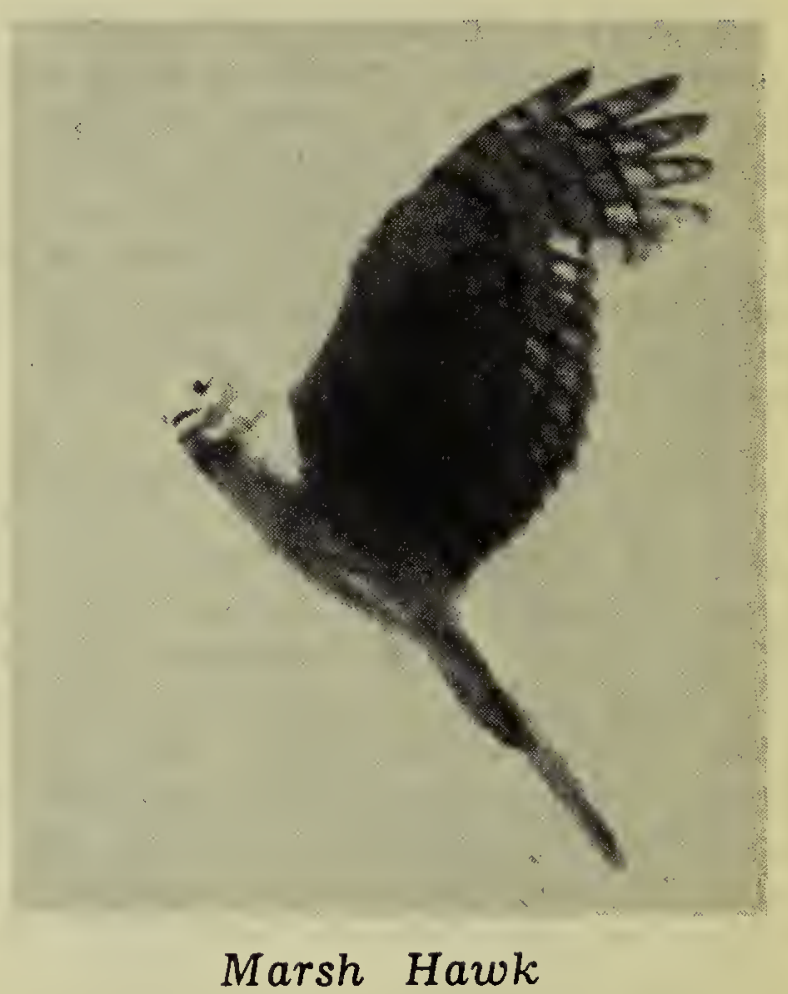

live in heavy forest they sit in trees and wait for their prey to move about. This is unusual for a buteo, as the others usually watch for their prey from the air.

THE SWAINSON'S HAWK feeds on small mammals. Sometimes they follow farm implements and catch mice as they scatter for safety.

THE AMERICAN ROUGH-LEGGED HAWK - feeds on mice. These birds do a lot of perching in the morning, and most of their feeding in the afternoon and evening. They also hunt at night.

THE MARSH HAWK - feeds mostly on mammals, but also catches some birds, My brother has seen it persistently hunting snipes. The accompaning photograph shows one on the look-out. When photographed she was flying above her nest.

THE GYRFALCON - feeds on birds. We once saw one of the white color phase, feeding on blood in the snow where a deer had been killed.

THE DUCK HAWK - feeds mostly on waterfowl. They probably do a great deal of good in hunting season by ending the sufferings, of wounded ducks.

THE PIGEON HAWK - feeds on birds. One day last November while in mixed forest, we heard a whir of 
wings, and looking up, saw a Ruffed Grouse fleeing in panic before a Pigeon Hawk - about twenty yds. behind him. The grouse landed on the ground and the falcon landed in a tree above him and waited in ambush. A shot, fired at him, soon changed his mind.

THE SPARROW HAWK - feeds on mice and insects. These birds will often so gorge themselves on mice that they will sit droopily in trees for hours while digestion does its work. Only rarely do they catch sparrows.

The diet of the GREAT HORNED OWL is said to be one-third birds, the rest mammals. However, I believe this is not true, but that about one-third of these birds have acquired a.taste for birds, while the others seldom touch them. One nest, we found, contained the nest of several rats, another contained the remains of varying Hares. In neither case was an incriminating feather found.

Once Great Horned Owls have acquired the taste for birds - guard your poultry. They will even kill geese and turkeys. Once we came upon a Great Horned Owl eating a Short-eared Owl. Such a cannibal! However, let's make sure of a Great Horned Owl's diet before we shoot him. It may cost you a hen, but what is that compared with innumerable rats and mice?

The SNOWY OWL - feeds on mice and hares, and also takes some game birds.

The SHORT-EARED OWL feeds almost entirely on mice. One day I saw a cat carrying a mouse, with an immature Short-eared Owl hovering low over his back and looking hungrily down at him with big, greedy eyes. He followed the cat up the lane and right to the house.

THE LONG-EARED OWL feeds mostly on mammals. Immature ones sometimes kill poultry.

Our hawks and owls are mostly beneficial, so let us do our best to protect them. Their destruction results in an upset in the balance of nature, so that there is an over abundance of mammalian pests, resulting in much destruction to our crops.

\section{The Chickadee}

John E. Nixon, Wauchope, Sask.

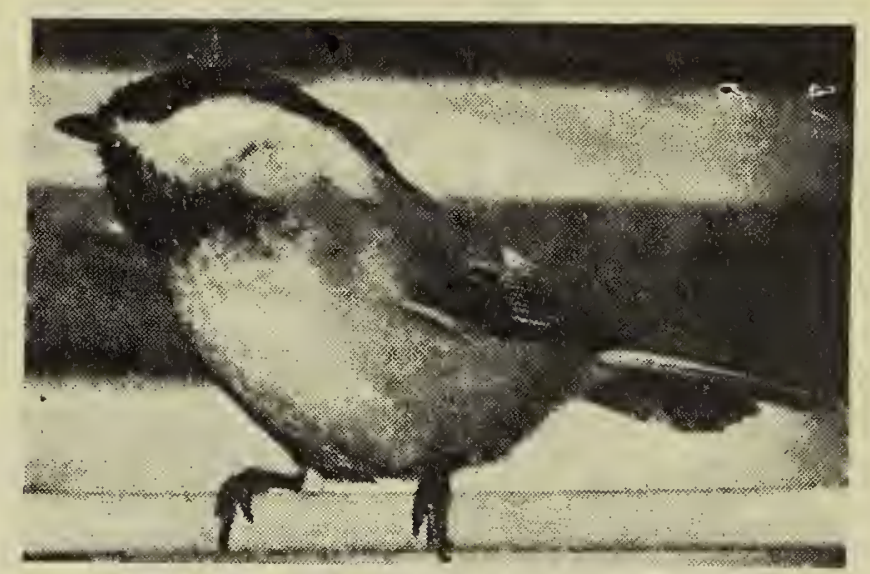

When all the world is robed in white

Then often comes a friendly sprite Among the leafless trees.

A black-capped, cheery little soul, Flitting about each bough and bole Completely at his ease.

Careless of wind or frost or snow, I see him gaily come and go A spirit of the groves.

The storms of winter try him not; Contented with his humble lot In merry mood he roves.

He seems to seek the ways I tread, And by my side, or overhead,

He gladly calls to me

With that clear note that loud and sweet

The silent winter woods repeat

Of chick-a-dee-dee-dee.

From bough to bough he quickly wings

Or to a nodding grass stem clings, Audacity itself.

Less dreary are these winter days For his confiding, friendly way,

The fearless, feathered elf!

WINTER'S PERFUME - 13-14MB (Continued from Page 2)

dead dank leaves, wet logs, we felt, strangely, a sea - weed - laden breeze from Fundy Bay and were once again breathing deep the salty air. Emotions provoked by smell, how real and lasting.

A bush rabbbit hurrying past a rose bush on the bank - the fat crimson haws gleaming, making a patch of splendor in the snow, brought us back to the present. But the glorious scene and the fragrance of this day would be recalled again and again.

"Remembered joys are never past,

They were, they are, they yet shall be." 